\title{
Przedmowa: Innowacje społeczne między rynkiem a państwem
}

Innowacje to przejaw fenomenu ludzkiej woli i rozumu, wynik poszukiwania rozwiązań dających uczucie szeroko rozumianego komfortu. Jednakże "(...) do podjęcia działania nie wystarczy uczucie dyskomfortu i wyobrażenie bardziej zadawalającego stanu rzeczy. Konieczne jest spełnienie trzeciego warunku: przekonanie, że celowe zachowanie może doprowadzić do usunięcia lub przynajmniej zmniejszenia niepokoju" (Mises, 2007, s. 11). Przejawem zrozumienia sprawstwa w obszarze kreowania świata w swoim otoczeniu jest zaradność społeczna objawiająca się aktywnością, zarówno jednostek, jak i społeczności. Ta aktywność, jeśli łączy w sobie cele gospodarcze ze społecznymi, przybiera postać przedsiębiorczości społecznej, a jej rezultatami są innowacje w obszarze społecznym. Według Martin i Osberga (2007) punktem wyjścia innowacyjności społecznej jest identyfikacja trwałej i niesprawiedliwej dysproporcji, której efektem jest wykluczenie, marginalizacja, czy też cierpienie pewnych grup ludzi.

Od ogłoszenia Strategii Lizbońskiej innowacje stały się wiodącym celem wielu współczesnych gospodarek europejskich. Efektem takiej orientacji jest powszechność pojęcia „innowacja”, która przejawia się jego wykorzystywaniem w odniesieniu do „wszystkich sfer życia, począwszy od nowych, lepszych, bardziej postępowych rozwiązań dotyczących życia gospodarczego czy społecznego, a skończywszy na nowych prądach myślowych i kulturalnych" (Janasz i Kozioł-Nadolna, 2011, s. 11). Stanisławski wysnuwa wniosek, że wdrożenia innowacji "stanowią podstawowy warunek zrównoważonego rozwoju nie tylko samych przedsiębiorstw, ale całej zarówno krajowej, jak i europejskiej gospodarki" (Stanisławski, 2017, s. 52).

Trudno nie zauważyć, że dla większości organizacji współczesna rzeczywistość jest bardzo wymagająca. Postęp technologiczny, rosnąca konkurencja, wzrost wymagań klientów, niepewność w obszarze regulacji prawnych - to tylko niektóre z przyczyn tej sytuacji. W tak złożonym, turbulentnym środowisku, umiejętność wyczuwania zmian i szybka i innowacyjna reakcja na nie, jest ważnym wyznacznikiem sukcesu. Znaczenie innowacji dla przedsiębiorstw i gospodarek przejawia się wzrostem zainteresowania wskazaną problematyką w równym stopniu przez praktyków, jak i teoretyków, którzy swoją uwagę kierują w stronę takich problemów jak: określanie zewnętrznych i wewnętrznych uwarunkowań rozwoju innowacji, tworzenie dynamicznych zdolności innowacyjnych, analiza czynników kulturowych wpływających na generowanie i wdrażanie innowacji, wdrażanie w życie nowych koncepcji rozwojowych (Elmquist i in., 2009).

Otoczenie przedsiębiorstwa (bliższe: konkurencyjne, mikrootoczenie oraz dalsze: ogólne, makrootoczenie) stwarza szereg czynników, które wpływają na procesy innowacyjne przedsiębiorstw. Część tego otoczenia pełni rolę stymulującą w procesie innowacyjnym: dostrzegają 
potrzebę innowacji, znajdują rozwiązanie, budują prototyp i sprawdzają jego wartość, inne (obszar nauki i techniki), zajmują się tworzeniem nowej wiedzy naukowej i technicznej przyjmującej postać wynalazków, nowych pomysłów racjonalizatorskich itp. Jeszcze inne (parki naukowe i technologiczne, inkubatory przedsiębiorczości) wspierają i pośredniczą w promowaniu. Po drugiej stronie stoją determinanty oddziałujące na procesy innowacyjne, pochodzą z otoczenia dalszego. To one decydują o ogólnych warunkach dla tworzenia i dyfuzji innowacji w gospodarce. Są to m.in.: rozwiązania instytucjonalne, organizacyjne i informacyjne państwa, polityka innowacyjna państwa, warunki instytucjonalno-rynkowe.

Jak można zaobserwować, śledząc historię gospodarczą i społeczną, odpowiedzią na niedostatki ekonomii neoliberalnej oraz na silnie rezonujące społecznie i gospodarczo błędy rynku było rosnące zapotrzebowanie na wzrost roli państwa w relacjach gospodarczych, i gospodarczo-społecznych (Morawski, 2001). Państwo w tym zamyśle miało stać się nie tylko strażnikiem, ale i silnym graczem w przestrzeni realnej gospodarki. Rozwój gospodarczy, w tym głównie industrializacja, miał znaczący wpływ na postępujące zmiany społeczne. Rozpad rodzin, wspólnot i społeczności lokalnych zmieniał tkankę społeczną na przełomie XIX i XX w. Deficyt powstały w ten sposób musiało likwidować państwo, przejmując obszar interwencji społecznych z poziomu rodziny oraz społeczności lokalnych. Efektem tego była wyraźnie rosnąca rola państwa w kształtowaniu stosunków społecznych, a także gospodarczych. Wiek XX to wiek wojen i kryzysów, których skutki musiało niwelować państwo. Im kraje i ich gospodarki bardziej się rozwijały, tym bardziej potrzebowały państwa i jego aktywnego udziału w kształtowaniu ładu społeczno-gospodarczego (Chmielewski, 2011). Dalszy rozwój gospodarek napędzanych wolnorynkowymi przepisami prowadził do rozwoju gospodarczego, ale równocześnie pogłębiał negatywne zjawiska społeczne wynikające wprost z gospodarki (bezrobocie), jak i będące jej pośrednim efektem (rozwarstwienie społeczne, bieda, słabo działająca służba zdrowia, rosnące nierówności, wykluczenie itd.) (Wilkin, 2012). Zmiany sposobu i zakresu działania państwa stały się przedmiotem badań. Jednym z takich badaczy był A. Wagner, który uznał za zjawisko naturalne rosnący udział państwa w gospodarce, rosnącą skalę interwencji, rosnące wydatki publiczne i w konsekwencji rosnące obciążenia podatkowe (Owsiak, 2017). Sformułowane na tej podstawie tzw. prawo Wagnera mówi, że rozwój społeczny prowadzi do wzrostu wydatków publicznych i wzrostu roli państwa w ogóle. Jest to efekt niezdolności rynku do zaspokajania potrzeb społecznych, szczególnie w wymiarze zbiorowym, a te - jak pokazują badania - rosną szybciej niż potrzeby jednostkowe (prywatne).

Tworzące się deficyty społeczne powinny wywoływać reakcje po drugiej stronie poprzez mobilizację do działania i organizowania się i w konsekwencji do powstawania inicjatyw i ruchów społecznych. Jednak słabość, a często nawet niezdolność do wspierania działań społecznych przez samo społeczeństwo pogłębia się (Czapiński i Panek, 2015; Helliwell i Putnam, 1995; Putnam, 2000). Państwo wkraczając w tę sferę, tworzy obszar wspieranej działalności, dzięki czemu możliwe staje się nie tylko trwałe funkcjonowanie formalnych podmiotów czy nieformalnych inicjatyw społecznych, ale również wewnętrzna dywersyfikacja formy, sposobu działania, obszarów oraz kierunków rozwoju działalności społecznej. Brak takiego wsparcia w wymiarze systemowym prowadzić będzie do tworzenia się słabo dofinansowanych inicjatyw społecznych i silnej koncentracji aktywów w obszarze charytatywnego wsparcia usług (Amin i Hausner, 1997).

Efektem systemowego braku wsparcia jest kierunkowa uniformizacja działalności społecznej szczególnie w zakresie obszarów prowadzonej działalności i samych sposobów działania. To zjawisko staje się główną barierą rozwojową dla całego społeczeństwa (Wilkin, 2012). W tym 
miejscu warto posłużyć się rozważaniami J. Schumpetera na temat efektywności alokacyjnej i adaptacyjnej. Ta pierwsza dotyczy efektywności w zakresie alokacji zasobów i ma wymiar krótkookresowy. Efektywność adaptacyjna odnosi się natomiast do efektywności gospodarczej, jak również społecznej, w długim okresie czasu, a jej fundamentem jest zdolność do generowania innowacji. Gdzie, jak podkreśla J. Hausner, pierwsza jest efektem konkurencji firm, a druga konkurencji form (Hausner, 2008). Oznacza to, że pierwsza efektywność jest efektem konkurencyjnego działania podmiotów rynkowych, natomiast efektywność adaptacyjna jest efektem silnego i wyraźnego zróżnicowania wewnętrznego całego systemu (Mikosik, 1993). To pokazuje, że tylko silne zróżnicowanie wewnętrzne zapewnia elastyczność systemu i zdolność do tworzenia zróżnicowanych i gospodarczo czy społecznie pożądanych innowacji - innowacji, które będą odpowiedzią na zmieniające się warunki, otoczenie, a nawet na zmiany wywołane wewnętrzną dynamiką systemu.

Patrząc z tej perspektywy, jedynym gwarantem trwałego i systemowego wsparcia dla inicjatyw społecznych jest państwo. Dzisiejsze państwo stało się ważnym graczem gospodarczym i społecznym. Brak państwa w gospodarce, jak i w obszarze społecznym oraz brak skutecznej polityki gospodarczej i społecznej skutkować będzie regresem, zarówno społecznym, jak i gospodarczym (Stiglitz, 2012). Z tej perspektywy wydaje się zasadne, że to państwa biorą na siebie odpowiedzialność za rozwój gospodarek i to nie tylko w efekcie prowadzenia polityki fiskalnej i monetarnej, ale dlatego, że stają się graczem prowadzącym aktywną politykę gospodarczą, w tym również - co raz szerzej zakrojoną - działalność innowacyjną. Niektórzy nawet idą o kilka kroków dalej i prezentują państwo jako głównego innowatora obecnych czasów, wskazując na niemożność tworzenia przełomowych innowacji bez udziału państwa (Mazzucato, 2017). Omawiana działalność innowacyjna jest efektem bezpośredniego działania państwa, jednak znacząca część działalności w tym obszarze odbywa się poprzez finansowanie/ współfinansowanie działalności lub jej kontraktowanie. To właśnie w ten sposób powstają największe i zarazem przełomowe innowacje w informatyce, telekomunikacji, medycynie, nanotechnologii. Podobnie w ten sposób państwo finansuje lub kontraktuje prace nad tworzeniem i rozwojem innowacji społecznych.

Dynamicznie zmieniające się otoczenie społeczno-gospodarcze w silny sposób wpływa na społeczeństwa. Dynamika tych procesów sprawia, że możliwość reakcji, zarówno z perspektywy indywidualnej, jak również systemowej, nie jest ani łatwa, ani często możliwa. Powstawanie deficytów w usługach społecznych i w ogóle w dostępie do usług publicznych zaczyna stanowić poważny problem społeczny i publiczny. Remedium na ten stan rzeczy mają stanowić działania realizowane w skali mikro, choć systemowo finansowane ze środków publicznych. Finansowanie projektów z zakresu innowacji społecznych jest przykładem tego typu działań. W ten sposób państwo realizuje znaczący projekt systemowy, w efekcie którego powstają mikro rozwiązania, które cechuje elastyczność, bliskość odbiorcy oraz łatwość dopasowania narzędzi i sposobu działania do specyfiki uczestników, rynku lokalnego, czy oczekiwań społeczności lokalnych.

Poddany analizie w poniższej publikacji obszar innowacji społecznych nie jest rozwiązaniem nowym, jednak dopiero teraz staje się on ważnym elementem działania trzech sektorów: rynku, państwa i społeczeństwa. Te trzy sektory instytucjonalnie i podmiotowo przenikają się, podobnie jak rozwiązania proponowane w ramach innowacji społecznych, które wykorzystują narzędzia używane przez każdy z nich do realizacji założonych celów (Bhattacharya, 2013). Determinanty publiczne, rynkowe i społeczne tworzą wspólnie silny związek czynników motywujących, wspierając aktywność gospodarczą i społeczną poprzez wykorzystanie bodźców 
wewnątrz motywacyjnych oraz motywacji zewnętrznej - ponieważ równie ważna jak efekt końcowy jest aktywizacja jednostek i całych społeczności (Lubimow-Burzyńska, 2015). Łącząc różne poziomy motywacji i wyznaczając realne cele społeczne tworzy się w ten sposób narzędzia o wysokim poziomie społecznej akceptacji i tym samym wdrażane są rozwiązania, których cele mają znaczące szanse na skuteczną realizację (Laurisz, 2018).

Celem niniejszej publikacji jest omówienie problematyki innowacji społecznych na kilku płaszczyznach. Punktem wyjścia jest rozdział Alicji Staszel, w którym autorka opisuje zagadnienie innowacji społecznych z perspektywy makro, przy założeniu całej specyfiki naszego kraju. W rozdziale tym wyjaśnione i opisane zostało zagadnienie innowacyjności oraz zaprezentowana i omówiona została złożoność procesowa tego zjawiska. Kolejnym krokiem było przedstawienie polskiej specyfiki zjawiska rozpoczęte analizą innowacyjności, a następnie szans i potencjału rozwojowego oraz zdolności do jego wykorzystania w obszarze społecznym.

Kolejny rozdział autorstwa Kingi Gaździckiej rozpoczyna się wyjaśnieniem problematyki i specyfiki zjawiska, następny krok stanowi poszukiwanie i interpretacja jego genezy. Zakończeniem tego rozdziału jest próbą prezentacji przykładów europejskich i polskich w obszarze innowacji społecznych.

Rozdział Adrianny Markowicz poświęcony został szczególnemu aspektowi innowacji społecznych, jakim jest tworzenie rozwiązań, których celem jest rozwój społeczny i, co ważne, podniesienie aktywności i skali partycypacji społeczeństwa.

Marta Kołodziej-Hajdo w rozdziale odnoszącym się do źródeł finansowania innowacji społecznych, wychodzi z założenia, że głównym narzędziem stymulowania innowacji społecznych są odpowiednie mechanizmy ich finansowania. Takie, które zwiększą efektywność organizacji i ich usług ukierunkowanych na innowacyjne rozwiązywanie problemów społecznych. Autorka zastanawiając się nad rolą finansowania innowacji społecznych, postuluje poszerzenie katalogu wsparcia o instrumenty znane, ale nie wykorzystywane w tym obszarze, jak np.: granty replikacyjne, instrumenty zwrotne (pożyczki), udziały czy ulgi podatkowe oraz tych bardziej nowatorskich jak: społeczne fundusze inwestycyjne czy bankowość społeczna. Dodatkowo, Autorka wnioskuje o podjęcie działań w zakresie rozwoju współpracy międzysektorowej (współpraca biznesu z organizacjami społecznymi i sektorem publicznym) czy międzyorganizacyjnej, które pozwoliłyby na stworzenie finansowania hybrydowego. Z kolei w odniesieniu do powszechnych źródeł finansowania innowacji społecznych takich jak środków unijnych czy grantów, postuluje uproszczenie procedur aplikacyjnych.

W obszarze tematyki wspierania inicjatyw społecznych znalazł się również rozdział Magdaleny Pilarczyk i Macieja Woźniaka. Zaprezentowane zostało w nim spojrzenie na innowacje społeczne w Unii Europejskiej przez pryzmat pomocy publicznej. Punktem wyjścia dla Autorów jest założenie, że koncepcja zawodności rynku wskazuje na potrzebę wspierania inicjatyw społecznych różnego rodzaju programami. Przeprowadzone w rozdziale badania wskazują, że Unia Europejska wprowadziła szereg inicjatyw umożliwiających finansowanie nowatorskich projektów, które oddziaływać mają na wybrane grupy społeczne lub całe społeczeństwo.

Rozdział autorstwa Anny Stronczek i Weroniki Kotyzy skupia się na technologiach mobilnych i ich roli jako narzędzi wsparcia dla innowacji społecznych. Autorki poddają analizie rozpowszechnienie się technologii mobilnych oraz rozmiar ich zastosowania, na które wpływ mają m.in.: mobilność nowych urządzeń, ich osobisty charakter, intuicyjna i prosta obsługa, niewielkie koszty, możliwość stałego podłączenia do Internetu, szeroka oferta aplikacji, wielofunkcyjność. Te atrybuty powodują, iż technologie mobilne mają swój udział w rozwoju gospodarki elektronicznej i pełnią ważną rolę w podnoszeniu innowacyjności oraz konkurencyjno- 
ści organizacji. Efektem badań Autorek jest stworzenie nowatorskiego arkusza audytu cech i atrybutów innowacji społecznych. Za jego pomocą Autorki badały przykładową innowację wykorzystującą technologie mobilne, tym samym weryfikując użyteczność opracowanego narzędzia badawczego.

Monografia, którą oddajemy w Państwa ręce to zbiór rozważań, które problematykę innowacji społecznych podejmują w bardzo szerokiej i holistycznej perspektywie.

Norbert Laurisz, Anna Stronczek

Redaktorzy

\section{Literatura}

Amin, A., Hausner, J. (red.). (1997). Beyond Market and Hierarchy: Interactive Governance and Social Complexity. Cheltenham: Edward Elgar Publishing.

Bhattacharya, C. (2013). The Importance of Marketing for Social Innovation. W: T. Osburg, R. Schmidpeter (red.). Social Innovation: Solutions for a Sustainable Future (s. 147-154). Heidelberg: Springer.

Chmielewski, P. (2011). Homo agens. Warszawa: Wydawnictwo Naukowe PWN.

Czapiński, J., Panek, T. (2015). Diagnoza Społeczna 2015. Warunki i jakośćżycia Polaków. Warszawa: Rada Monitoringu Społecznego.

Elmquist, M., Fredberg, T., Ollila, S. (2009). Exploring the field of open innovation. European Journal of Innovation Management, 12(3), 326-345. https://doi.org/10.1108/14601060910974219

Hausner, J. (2008). Zarządzanie publiczne. Warszawa: Scholar.

Helliwell, J.F., Putnam, R.D. (1995). Economic Growth and Social Capital in Italy. Eastern Economic Journal, 21(3), 295-307.

Janasz, W., Kozioł-Nadolna, K. (2011). Innowacje w organizacji. Warszawa: Polskie Wydawnictwo Ekonomiczne.

Laurisz, N. (2018). Polityka społeczna. Od aksjologii do akceptacji społecznej. Ekonomia Społeczna, 2, 82-89. https://doi.org/10.15678/ES.2018.2.10

Lubimow-Burzyńska, J. (2015). Proces tworzenia innowacji społecznych. W: J. Wyrwa (red.). Innowacje społeczne w teorii i praktyce (s. 72-93). Warszawa: Polskie Wydawnictwo Ekonomiczne.

Martin, R. J., Osberg, S. (2007). Social entrepreneurship: The case for a definition. Stanford Social Innovation Review, 5(2), 28-39.

Mazzucato, M. (2017). Przedsiębiorcze państwo. Obalić mit o relacji sektora publicznego i prywatnego. Poznań: Wydawnictwo Ekonomiczne Heterodox.

Mikosik, S. (1993). Teoria rozwoju gospodarczego Josepha A. Schumpetera. Warszawa: Wydawnictwo Naukowe PWN.

Mises, L. von (2007). Ludzkie działanie. Traktat o ekonomii. Warszawa: Instytut Ludwiga von Misesa.

Morawski, W. (2001). Socjologia ekonomiczna: Problemy, teoria, empiria. Warszawa: Wydawnictwo Naukowe PWN.

Owsiak, S. (2017). Finanse publiczne. Warszawa: Wydawnictwo Naukowe PWN.

Putnam, R. D. (2000). Bowling Alone: America's Declining Social Capital. W: L. Crothers, C. Lockhart (red.). Culture and Politics: A Reader (s. 223-234). London: Palgrave Macmillan.

Stanisławski, R. P. (2017). Open innovation a rozwój innowacyjny mikro, małych i średnich przedsiębiorstw. Łódź: Wydawnictwo Politechniki Łódzkiej.

Stiglitz, J. (2012). Globalizacja. Warszawa: Wydawnictwo Naukowe PWN.

Wilkin, J. (2012). Teoria wyboru publicznego. Główne nurty i zastosowania. Warszawa: Scholar. 


\section{Informacje o autorach}

\section{Norbert Laurisz}

ORCID: 0000-0003-2079-1041

Katedra Zarządzania Organizacjami Publicznymi Kolegium Gospodarki i Administracji Publicznej

Uniwersytet Ekonomiczny w Krakowie

ul. Rakowicka 27, 31-510 Kraków

e-mail: norbert.laurisz@uek.krakow.pl

\section{Anna Stronczek}

ORCID: 0000-0001-9343-936X

Katedra Ekonomii, Finansów i Zarządzania

Środowiskiem

Wydział Zarządzania

AGH Akademia Górniczo-Hutnicza w Krakowie

ul. Gramatyka 10, 30-067 Kraków

e-mail: astroncz@zarz.agh.edu.pl

\section{Prawa autorskie i licencja / Copyright and License}

(c) $(1) \Theta$

Publikacja na licencji Creative Commons Uznanie autorstwa Użycie niekomercyjne - Bez utworów zależnych 4.0 Międzynarodowe (CC BY-ND 4.0) http://creativecommons.org/licenses/by-nc-nd/4.0/deed/pl

This work is published under the terms of the Creative Commons Attribution - NoDerivetives International (CC BY-ND 4.0) License http://creativecommons.org/licenses/by-nc-nd/4.0

Wydane przez Uniwersytet Ekonomiczny w Krakowie. Małopolska Szkoła Administracji Publicznej

Published by Cracow University of Economics - Krakow, Poland. Małopolska School of Public Administration of the Cracow University of Economics 